\title{
Autoimmune Thyroid Disease in Children with Mongolism
}

\author{
DAGFINN AARSKOG \\ From the University of Bergen, School of Medicine, Department of Paediatrics, Bergen, Norway
}

\begin{abstract}
Thyroid function in mongol children has attracted the attention of investigators for many years. Certain clinical similarities between mongolism and cretinism have led, not only to misdiagnosis, but even to the suggestion that altered thyroid function might play a part in the clinical manifestations of mongolism. Much of the earlier use of thyroid therapy in patients with this syndrome was based on this assumption. The results of thyroid function studies in patients with mongolism have been controversial; some have been suggestive of thyroid insufficiency, whereas others have been more in keeping with thyroid overactivity (Kurland et al., 1957; Jackim, Wortis, and Adesman, 1961). However, most patients are clinically euthyroid, and, so far, no conclusive evidence of altered thyroid function in this group of patients has been presented.

The purpose of this paper is to report 3 cases of mongolism with coexisting hyper- or hypothyroidism, and to present the growing evidence for a relation between mongolism and thyroid autoimmunity.
\end{abstract}

\section{Case Histories}

Case 1. This 7-year-old girl was admitted to the Children's Hospital in Bergen in October 1964, because of goitre, exophthalmos, and heat intolerance. She was the second child of healthy parents. The mother was 34 and the father 36 when the child was born. There was no known case of mental retardation or thyroid disorder among her relatives.

Her motor and mental development was grossly retarded, and the diagnosis of mongolism was suspected from the first year of life. The parents stated that the child had had conspicuously prominent eyes since she was 2 to 3 years of age. For the last 2 years or so before the admission, she had been intolerant to heat and sweated profusely during the night. She had not displayed any particular nervousness, fatigue, or polyphagia, and she had not lost weight. There had been no tendency to loose or frequent bowel movements.

Received January 27, 1969.
Physical examination showed a restless child with the typical features of mongolism and hyperthyroidism (Fig.). The skin was warm and moist. There was no tremor. There was a marked exophthalmos, but no inability to converge.

Height was $117 \mathrm{~cm}$. (10th centile) and weight $21 \cdot 1 \mathrm{~kg}$. (50th centile). Her temperature was $37 \cdot 7^{\circ} \mathrm{C}$. and pulse rate 160 . Blood pressure was $130 / 65 \mathrm{~mm}$. Hg. The thyroid gland was diffusely enlarged, with firm consistency. A soft systolic murmur was heard at the left sternal border. The bone age was 6 years (Greulich and Pyle standard). Complete blood cell counts and urine analysis were normal; ESR $28 \mathrm{~mm}$./hr. Serum cholesterol was $220 \mathrm{mg} .100 \mathrm{ml}$. and protein-bound iodine $18.0 \mu \mathrm{g} . / 100 \mathrm{ml}$. The basal metabolic rate was $145 \%$.

Chromosome analysis gave a modal number of 46 chromosomes, with a $D / G$ translocation. The mother was a translocation carrier, with a modal number of 45 chromosomes including a $\mathrm{D} / \mathrm{G}$ translocation chromosome. The father had a normal karyotype.

The patient was treated with an initial dose of $20 \mathrm{mg}$. carbimazole administered in 3 divided doses. Within 8 weeks of treatment she was considered euthyroid and was discharged on a daily maintenance dose of $5 \mathrm{mg}$. carbimazole. This treatment was continued for 3 years. Six months after therapy was stopped she was still euthyroid. At that time the patient's and the parents' sera were tested for antithyroglobulin antibodies by the tanned red cell haemagglutination test. The patient was seropositive, with a titre of 320 , whereas both parents were seronegative.

Case 2. This case has been reported previously without data on cytogenetics and thyroid antibodies (Lunde, 1959).

The patient was a $9 \frac{1}{2}$-year-old girl born in 1949 . She was the fifth child of a 46-year-old mother and a 42-year-old father. During the years 1934-36 the mother received a course of $x$-ray therapy for thyrotoxicosis. There was no other case of thyroid disease or other endocrine disorder in the family, and no other case of mental retardation. The diagnosis of mongolism was suspected at birth, and motor and mental development were severely retarded. She hrd tendency to constipation since the first year of life. At the age of 5-6 years the parents noted that her voice became 


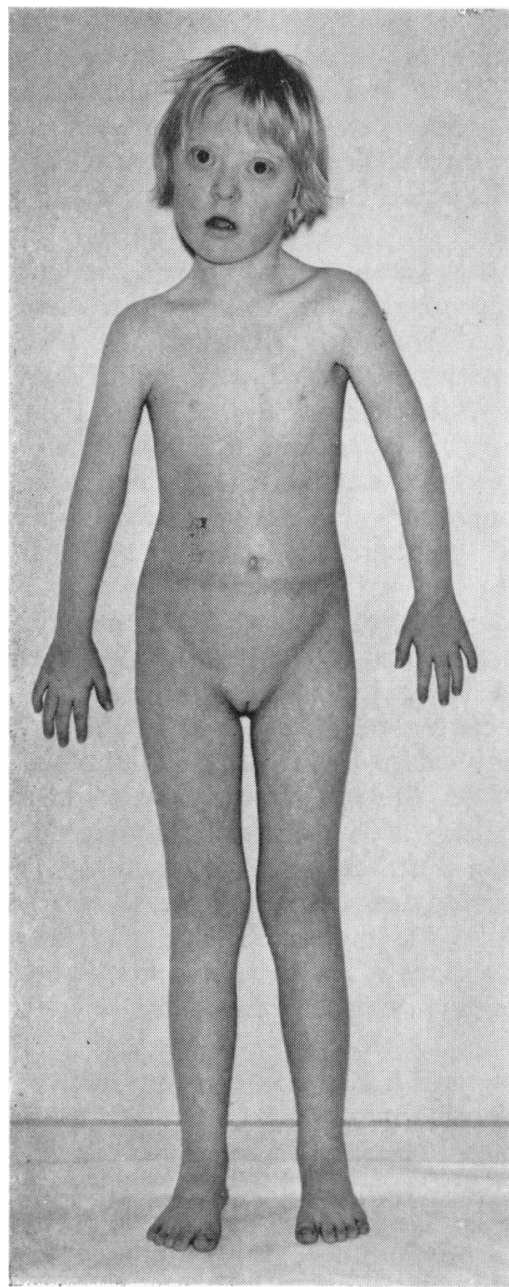

Fig.-Case 1. The features of both mongolism and hyperthyroidism are evident.

coarse, and during the past few years before admission they had been concerned about an increasing obesity. When $9 \frac{1}{2}$ she had a menstrual bleeding which lasted for 4 days.

On admission, she presented the typical features of mongolism. In addition, her skin was dry, scaly, and thickened, with a myxoedematous appearance. Her voice was coarse. There was no pubic or axillary hair and no breast development. Her height was $124 \mathrm{~cm}$. (10-2.5 centile) and weight $45 \mathrm{~kg}$. (16.5 kg. above 97.5 centile). The pulse rate was 60 and the blood pressure $90 / 60 \mathrm{~mm}$. $\mathrm{Hg}$. The thyroid gland was not palpable. Her bone age was 10 years (Greulich and Pyle standard). $X$-ray survey of the skeleton revealed no sign of epiphysial dysgenesis. Complete blood counts and urine analysis were normal; ESR $29 \mathrm{~mm}$./hr. Serum cholesterol was $353 \mathrm{mg} . / 100 \mathrm{ml}$., and protein- bound iodine $1.9 \mu \mathrm{g} . / 100 \mathrm{ml}$. The basal metabolic rate was $64 \%$. After ingestion of ${ }^{131} \mathrm{I}$ the urinary excretion of radioiodine was $48 \%$ of administered dose in 24 hours.

Treatment with desiccated thyroid was started, and was followed by the disappearance of the myxoedematous features and acceleration of linear growth. She had no further menstrual bleeding before she went into normal puberty at $13 \frac{1}{2}$ years. Chromosome analysis showed 47 chromosomes, with 'regular' 21-trisomy. Sera from the patient and both parents were tested for antithyroglobulin antibodies by the tanned red cell haemagglutination technique when she was 19 . The patient and her mother were seropositive, with titres of 80 and 640 , respectively. The father was seronegative.

Case 3. This was a 15 -month-old girl, the third child of a 42-year-old mother and a 39-year-old father. Both sibs and the parents were healthy, and there was no known case of thyroid disorder or mental retardation among relatives. Her birthweight was $3640 \mathrm{~g}$. and length $51 \mathrm{~cm}$. Clinical features of mongolism had been noted soon after birth, and the diagnosis was established when she was 6 months old. At that age her height was $62 \mathrm{~cm}$. (10-2.5 centile). Signs of hypothyroidism were not evident. From then on a slowing of growth was noted. She was very sluggish, and her motor development was unduly slow even for a child with mongolism.

Clinical examination at the age of 15 months showed features of both mongolism and hypothyroidism. She was sluggish with a pronounced hypotonicity. She was unable to sit without support. The skin was dry and mottled and the hair sparse and dry. The voice was deep and coarse. Her height was $67 \mathrm{~cm}$. $(5 \mathrm{~cm}$. below 2.5 centile) and weight $6.9 \mathrm{~kg}$. (25-10 centile). The thyroid gland was not palpable. The abdomen was distended with an umbilical hernia. There was a considerable retardation in osseous development, and the bone age was between 3 and 6 months (Greulich and Pyle standard). $X$-ray survey of the skeleton did not reveal findings suggestive of epiphysial dysgenesis. Complete blood cell counts and urine analysis were normal. Fasting blood sugar $49 \mathrm{mg} . / 100 \mathrm{ml}$. Serum protein-bound iodine $2 \cdot 1 \mu \mathrm{g} . / 100 \mathrm{ml}$. Chromosome analysis showed a modal number of 47 chromosomes, with one extra chromosome No. 21. At the age of 8 years her serum was tested for antithyroglobulin antibodies which were present with a titre of 80 . The mother was also seropositive, whereas the father was seronegative.

Treatment with desiccated thyroid resulted in gradual disappearance of all features of hypothyroidism. She became more alert, and after an initial catch-up growth, the linear growth proceeded in a channel near the 2.5 centile.

\section{Discussion}

At birth, the incidence of mongolism in populations of European origin is of the order of 1 in 700 (Penrose and Smith, 1966), and the prevalence 
among 10-year-old children is of the order 1 in 1000 (Carter, 1958). Figures for the prevalence of hypo- and hyperthyroidism in childhood derived from the general population are not available. However, the combined frequency of these disorders in non-endemic areas is undoubtedly of a lower order than that of mongolism. The expected frequency of a combination of mongolism and thyroid disorder from chance association is therefore most probably of the order of less than one in a million. Including the present cases, a total of 12 children have been reported in whom mongolism has coexisted with hypothyroidism (Table I). The association of mongolism and hyperthyroidism has been reported in 11 children under 16 years of age (Table II). It will be noted that the majority of reports have appeared during the past decade and with increasing frequency.

As already alluded to, there is growing evidence for some association between mongolism and immunological phenomena related to autoimmune thyroid disease. The suggestion that Hashimoto's thyroiditis, or chronic lymphocytic thyroiditis, is an autoimmune disease was first presented in 1956 by Roitt and associates who showed that many patients with Hashimoto's struma had circulating auto-antibodies to normal thyroid constituents. Since then, it has been well established that lymphocytic thyroiditis is a frequent cause of goitre in children (Saxena and Crawford, 1962; Leboeuf and Bongiovanni, 1964; Nilsson and Doniach, 1964; Hahn, Hayles, and Woolner, 1965). There is a high predominance of females over males, approximately 9 to 1 (Leboeuf and Ducharme, 1966). The peak incidence of lymphocytic thyroiditis in childhood is in the early pubertal period, and usually the children are euthyroid and present with a goitre. While thyroid antibodies occur only rarely in normal children, they are regularly present in lymphocytic thyroiditis (Lebocuf and Ducharme, 1966). Though this relation does not imply that circulating antibodies directly cause the goitre and the eventual thyroid atrophy, the demonstration of such antibodies is useful in diagnosing thyroiditis in childhood. Many patients with both juvenile and adult hypothyroidism also have thyroid antibodies, and there is increasing evidence that this disorder is the end result of lymphocytic thyroiditis (Owen and Smart, 1958; Leboeuf and Ducharme, 1966). Indeed, it has been suggested that chronic lymphocytic thyroiditis is the most common cause of acquired hypothyroidism in childhood (Winter, Eberlein, and Bongiovanni, 1966). Similarly, many patients with hyperthyroidism have thyroid antibodies, and it has been suggested that this disease may have an autoimmune basis (Anderson et al., 1964). Saxena (1965) studied thyroid antibodies in 12 children with proven thyrotoxicosis and their parents. Antibodies were found in all but one of the children and in one or other parent of 10 of them.

Hereditary factors seem to play a part in aetiology or pathogenesis, since thyroid antibodies and thyroid disease are frequently found in the parents and sibs of patients (Hall, Owen, and Smart, 1960; Doniach, Nilsson, and Roitt, 1965; Foley et al., 1968). Fialkow et al. (1965a) examined the incidence of thyroid disease in 44 families of patients with mongolism, and compared the findings with an equal number of control families from the same area and with maternal ages at the time of examination, matching those of the mongol families. Thyroid abnormality was found in 9 of 44 mothers $(20 \%)$ of mongol patients as opposed to 3 of 44 ( $7 \%$ ) of control mothers. 3 of the 9 mothers had Hashimoto's thyroiditis. 2 of 42 fathers of mongol patients had clinical thyroid disease, whereas none of the fathers in the control group was scored as abnormal. Further convincing facts were obtained when grandparents and great-grandparents were included in the evaluation, and altogether 21 of $44(48 \%)$ mongol patients, as opposed to 9 of 44 $(20 \%)$ control cases, had family histories of thyroid disease.

Fialkow and his associates went on to study the incidence of thyroid antibodies in 148 mothers of mongol children, using as controls blood bank donors from the same geographical area, matched for age (Fialkow et al., 1965). 42 of 148 $(28 \%)$ of the mothers of mongol children were seropositive in contrast to $21(14 \%)$ seropositive control women. The incidence of seropositivity in mothers of mongol children did not differ significantly throughout the different age ranges, whereas the incidence in the control group increased notably with age, reaching a frequency similar to that seen in mothers of mongol patients. The most significant difference was found in the younger age-group (20-32 years) where $27 \%$ of the mothers of mongol patients were seropositive, in contrast to $4 \%$ in the control group. When the mothers were divided into two groups, i.e. a younger group who had their affected child when they were under 35 years, and an older group representing a maternal age of 35 years or over, it was found that the seropositivity was almost confined to the younger mothers (Fialkow, 1967).

Examination of thyroid antibodies in patients with Down's syndrome has been the object of 
TABLE I

Reported Cases of Mongolism Associated with Hypothyroidism

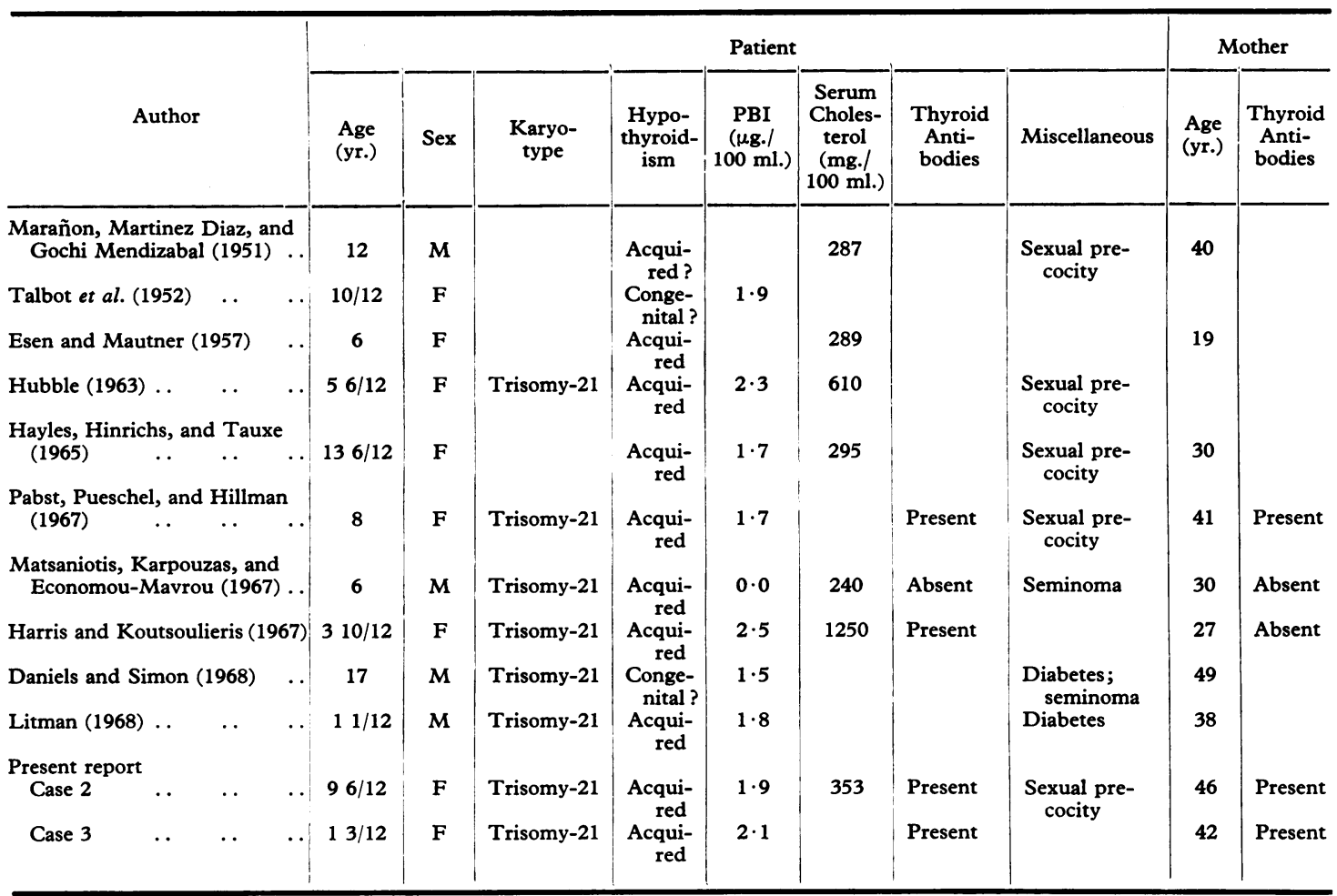

several studies. Mellon, Pay, and Green (1963) and Robertson, Mellon, and Stewart (1965) studied 35 mongol patients in an institution, and found thyroid antibodies in 7 in contrast to none in a group of 35 institutionalized controls matched for age, sex, and intelligence. In another series of

TABLE II

Reported Cases of Mongolism Associated with Hyperthyroidism

\begin{tabular}{|c|c|c|c|c|c|c|c|c|}
\hline Author & & $\begin{array}{c}\text { Mother's } \\
\text { Age } \\
\text { (yr.) }\end{array}$ & $\begin{array}{c}\text { Patient's } \\
\text { Age } \\
\text { (yr.) }\end{array}$ & Sex & Karyotype & $\begin{array}{c}\text { PBI } \\
(\mu \mathrm{g} . / \\
100 \mathrm{ml} .)\end{array}$ & $\begin{array}{c}\text { Serum } \\
\text { Choles- } \\
\text { terol } \\
\text { (mg./ } \\
100 \mathrm{ml} .)\end{array}$ & Miscellaneous \\
\hline $\begin{array}{l}\text { Dupuy and Garcia Ma Irigal } \\
\quad(1957) \quad \ldots \\
\text { Esen and Mautner (1957) } \\
\text { Diggle and Weetch (1958) } \\
\text { Nickey (1960) . . } \ldots \\
\text { Johnson and Cook (1962) } \\
\text { Kay and Esselborn (1963) } \\
\text { Hayles et al. (1965) . . } \\
\text { Subrt, Blehová, and Kučera } \\
\text { (1968) . . . } \\
\text { Present report, Case } 1 . .\end{array}$ & $\begin{array}{l}\cdots \\
\cdots \\
\cdots \\
\cdots \\
\cdots \\
\cdots \\
\cdots \\
\cdots \\
\cdots\end{array}$ & $\begin{array}{l}43 \\
40\end{array}$ & $\begin{array}{cl} & 15 \\
15 & 6 / 12 \\
6 & 6 \\
11 & 11 / 12 \\
14 & \\
& \\
9 & 6 / 12 \\
13 \\
13 \\
14 \quad 7 / 12 \\
& \\
& 6 \\
7 & \end{array}$ & $\begin{array}{c}\text { F } \\
\text { F } \\
F \\
F \\
F \\
\text { F } \\
\text { F } \\
\text { F } \\
\text { F } \\
\text { M } \\
\text { F }\end{array}$ & $\begin{array}{l}\text { Trisomy-21 } \\
\text { Trisomy-21 } \\
\text { D/G trisomy }\end{array}$ & $\begin{array}{r}14 \cdot 5 \\
20 \cdot 0 \\
10 \cdot 9 \\
14 \cdot 5 \\
14 \cdot 0 \\
11 \cdot 0 \\
9 \cdot 5 \\
18 \cdot 0\end{array}$ & $\begin{array}{l}180 \\
152 \\
130 \\
124 \\
200\end{array}$ & $\begin{array}{l}\text { Brother juvenile } \\
\text { myxoedema } \\
\text { Diabetes } \\
\text { Diabetes } \\
\text { Diabetes } \\
\text { Thyroid antibodies } \\
\text { present }\end{array}$ \\
\hline
\end{tabular}


75 mongols, Fialkow and co-workers (1965b) found 13 seropositive, and 12 of them were 25 years or less. Burgio and his colleagues (1965) studied 12 mongol children and found thyroid antibodies in $\mathbf{7}$, in contrast to 3 seropositive in $\mathbf{4 8}$ controls. In a larger series of 50 mongol children aged 1 to 15 years, there were $14(28 \%)$ with agglutinating antibodies to thyroglobulin (Saxena and Pryles, 1965): 30 mentally retarded children from the same institution, matched for age and sex, served as controls and thyroid antibodies were found in 2 instances $(7 \%)$.

These data indicate that mongol children might have a predisposition to autoimmune thyroid disease. On the assumption that congenital and acquired hypothyroidism, and that hypo- and hyperthyroidism have the same likelihood of being reported, such a predisposition should presumably be reflected by the relative frequency of the different types of thyroid disorder. In Table III the reported cases of thyroid disorder associated with mongolism have been compared with a series of children with thyroid disease attending the Endocrine Clinic of Harriet Lane Home (Wilkins, 1965). With due reservation for the small number

\section{TABLE III}

Frequency of Thyroid Disorders in Reported Cases of Mongol Children, Compared with Children Attending Endocrine Clinic (Harriet Lane Home)

\begin{tabular}{l|c|c}
\hline & $\begin{array}{c}\text { 23 Mongol } \\
\text { Children }\end{array}$ & $\begin{array}{c}\text { 256 Children } \\
\text { Attending Endo- } \\
\text { crine Clinic }\end{array}$ \\
\hline $\begin{array}{l}\text { Hypothyroidism } \\
\text { Congenital } \\
\text { Acquired } \\
\text { Hypothyroidism, all types }\end{array}$ & $\frac{10}{12}$ & $\frac{167}{45}$ \\
$\begin{array}{l}\text { Hyperthyroidism } \\
\text { Total }\end{array}$ & $\frac{11}{212}$ \\
\hline
\end{tabular}

of children in the mongol group, the most striking feature is the paucity of congenital hypothyroidism in this group. This effect is in accordance with the presupposition that mongol children have a predisposition to develop autoimmune thyroid disease. The relation between the frequency of acquired hypothyroidism and hyperthyroidism seems to be similar in the two groups of children. There is a preponderance of females both in acquired hypothyroidism (Table I), and especially in hyperthyroidism (Table II). The latter finding is in accordance with that observed in two larger series of children with hyperthyroidism. In a series from the Mayo Clinic, the ratio of females to males was 6 to 1 (Hayles et al., 1959), and in Wilkins' (1965) series from the Harriet Lane Home the ratio was 4 to 1 . The ratio in this small series of mongol children is closer to the 9 to 1 ratio observed in children with lymphocytic thyroiditis. Thyroid antibodies were seen in 4 of 5 cases of acquired hypothyroidism tested and in 3 of the 5 mothers. Only one child in the hyperthyroid group was tested for thyroid antibodies, and she was seropositive, whereas both parents were seronegative. 3 of the children with hyperthyroidism had a family history of thyroid disorder. In the hypothyroid group, there were statements on thyroid disorders in the family in 5 of the reported cases, and a positive history in 2 of them: 2 of the children in the hypothyroid group and 3 in the hyperthyroid had concomitant diabetes mellitus in addition to thyroid disease and mongolism. This is noteworthy because of the raised incidence of thyroid antibodies and Hashimoto's thyroiditis in patients with diabetes (Landing et al., 1963; Moore and Neilson, 1963).

An increased incidence of autoimmune thyroid disease and thyroid antibodies has also been observed in Turner's syndrome. Originally this association was thought to be limited to patients with gonadal dysgenesis and $\mathrm{X}$-isochromosome (Engel and Forbes, 1961; Sparkes and Motulsky, 1963; Grumbach and Morishima, 1964). However, subsequent work has shown that patients with Turner's syndrome and their parents have a higher incidence of thyroid antibodies than controls, and that there is no correlation between these findings and the karyotype of the patient (Vallotton and Forbes, 1967). Since neither the mechanism giving rise to auto-antibody formation, nor that responsible for chromosomal abnormalities is known, there are two possibilities that would explain the association of the two phenomena. Chromosomal disorder could be primary and existing chromosomal anomalies might give rise to auto-immunity. Alternatively, auto-immunity or a related factor may predispose to chromosomal aberration. The latter hypothesis has in particular been advocated by Fialkow (1966). The high frequency of thyroid antibodies in mongol patients and in those with gonadal dysgenesis does not seem simply to be the result of their chromosomal abnormalities, since the parents, who do not themselves have such abnormalities, also have a high incidence of autoimmunity when compared with age-matched controls. It is well known that females have a higher incidence of circulating auto-antibodies and a higher incidence of most of 
the disorders which are associated with them than males. It is also well documented that the incidence of auto-antibodies increases with increasing age. These factors are relevant in mongolism, since the non-disjunctional event leading to this disorder has a clear relation with advanced maternal age. However, advanced maternal age is not related to the XO Turner syndrome, and nondisjunction has more often been traced to the paternal than to the maternal $\mathrm{X}$ chromosome (Lindsten et al., 1963).

Chromosome analysis in patients with mongolism and thyroid antibodies has shown both regular trisomy-21 and the more unusual karyotypes. In one series with 7 seropositive patients, there was one with normal/trisomy-21 mosaicism, one with $D / G$ translocation, and one with $G / G$ translocation (Robertson et al., 1965). It is of interest that mosaicism has also been found in 3 patients with mongolism whose mothers had Hashimoto's thyroiditis and/or thyroid antibodies (Fialkow, 1967). Chromosome analysis has been carried out in 8 of the cases with mongolism associated with acquired hypothyroidism, and all of them showed regular trisomy-21 (Table I). Only 3 children in the hyperthyroid group were karyotyped: 2 of them had regular trisomy-21. The third, Case 1 in the present report, showed an inherited $D / G$ translocation, and is of particular interest in the discussion of whether the thyroid antibodies, or a factor related to them, cause the chromosomal abnormality, since the child was seropositive whereas the mother, who was the $D / G$ translocation carrier, was seronegative.

In conclusion, there is a fair amount of circumstantial evidence that mongolism and thyroid autoimmune disease are associated, but the role of thyroid autoimmune phenomena in causing chromosome aberrations is at present uncertain.

\section{Summary}

Three girls with mongolism associated with thyroid disorder are reported. One child had hyperthyroidism, and the other two had acquired hypothyroidism. One of the latter had precocious menstrual bleeding at the age of $9 \frac{1}{2}$ years. Chromosome analysis showed regular trisomy-21 in both children with hypothyroidism, and thyroid antibodies were present in both the mothers and the children. The child with hyperthyroidism had $\mathrm{D} / \mathrm{G}$ translocation trisomy, and thyroid antibodies were present in her serum, whereas the mother who was $\mathrm{D} / \mathrm{G}$ translocation carrier was seronegative.

A total of 11 children including the present cases, have been reported with the combination of mongolism and hyperthyroidism. The association with hypothyroidism has been reported in 12 children, and only 2 of them had congenital hypothyroidism.

There is growing evidence to support the suggestion that there is an association between mongolism and thyroid autoimmune disease.

\section{REFERENCES}

Anderson, J. R., Gray, K. G., Middleton, D. G., and Young, J. A. (1964). Autoimmunity and thyrotoxicosis. Brit. med. $\mathfrak{F}$., $2,1630$.

Burgio, G. R., Severi, F., Rossoni, R., and Vaccaro, R. (1965). Mongolism and thyroid autoimmunity. Lancet, $1,166$.

Carter, C. O. (1958). A life-table for mongols with the causes of death. F. ment. Defic. Res., 2, 64.

Daniels, D. M., and Simon, J. L. (1968). Down's syndrome, hypothyroidism, and diabetes mellitus. F. Pediat., 72, 697.

Diggle, J. H., and Weetch, R. S. (1958). Thyrotoxicosis in a mongol. Proc. roy. Soc. Med., 51, 293.

Doniach, D., Nilsson, L. R., and Roitt, I. M. (1965). Autoimmune thyroiditis in children and adolescents. II. Immunological correlations and parent study. Acta paediat. scand., 54, 260.

Dupuy, F. I., and Garcia Madrigal, R. (1957). Hipertiroidismo en un mongol. Arch. Hosp. univ. (Habana), 8, 389.

Engel, E., and Forbes, A. P. (1961). An abnormal medium-sized metacentric chromosome in a woman with primary gonadal failure. Lancet, 2, 1004.

Esen, F. M., and Mautner, H. (1957). Hypo- and hyperthyroidism in mongolism. Arch. Pediat., 74, 291.

Fialkow, P. J. (1966). Autoimmunity and chromosomal aberrations. Amer. F. hum. Genet., 18, 93.

(1967). Thyroid antibodies, Down's syndrome, and maternal age. Nature (Lond.), 214, 1253.

-, Hecht, F., Bryant, J., and Motulsky, A. G. (1965a). Familial predisposition to chromosomal aberrations. Clin. Res., 13, 124. , Uchida, I. A., Hecht, F., and Motulsky, A. G. (1965b) Increased frequency of thyroid autoantibodies in mothers of patients with Down's syndrome. Lancet, 2, 868.

Foley, T. P., Jr., Schubert, W. K., Marnell, R. T., and McAdams, A. J. (1968). Chronic lymphocytic thyroiditis and juvenile myxedema in uniovular twins. F. Pediat., 72, 201.

Grumbach, M. M., and Morishima, A. (1964). X-chromosome abnormalities in gonadal dysgenesis: DNA replication of structurally abnormal $\mathrm{X}$-chromosome: relation to thyroid disease. ibid., 65, 1087.

Hahn, H. B., Jr., Hayles, A. B., and Woolner, L. B. (1965). Lymphocytic thyroiditis in children. ibid., 66, 73.

Hall, R., Owen, S. G., and Smart, G. A. (1960). Evidence for genetic predisposition to formation of thyroid autoantibodies. Lancet, 2, 187.

Harris, F., and Koutsoulieris, E. (1967). Hypothyroidism due to autoimmune thyroiditis in a young child with Down's syndrome. Arch. Dis. Childh., 42, 449.

Hayles, A. B., Hinrichs, W. L., and Tauxe, W. N. (1965). Thyroid disease among children with Down's syndrome (mongolism). Pediatrics, 36, 608.

—, Kennedy, R. L. J., Beahrs, O. H., and Woolner, L. B. (1959). Exophthalmic goiter in children. f. clin. Endocr., 19, 138.

Hubble, D. (1963). Precocious menstruation in a mongoloid child with hypothyroidism-hormonal overlap. ibid., 23, 1302.

Jackim, E., Wortis, J. D., and Adesman, J. (1961). Triiodothyronine uptake by erythrocytes in mongolism. Proc. Soc. exp. Biol. (N.Y.), 107, 401.

Johnson, J. E., Jr., and Cook, A. R. (1962). Hyperthyroidism in patients with mongolism. f. clin. Endocr., 22, 665.

Kay, C. J., and Esselborn, V. M. (1963). Hyperthyroidism and mongolism: report of three cases. Amer. $\mathcal{F}$. Dis. Child., 106, 411.

Kurland, G. S., Fishman, J., Hamolsky, M. W., and Freedberg, A. S. (1957). Radioisotope study of thyroid function in 21 mongoloid subjects, including observations in 7 parents. $\mathcal{f}$. clin. Endocr., 17, 552. 
Landing, B. H., Pettit, M. D., Wiens, R. L., Knowles, H., and Guest. G. M. (1963). Antithyroid antibody and chronic thyroiditis in diabetes. ibid., 23, 119.

Leboeuf, G., and Bongiovanni, A. M. (1964). Thyroiditis in childhood. Advanc. Pediat., 13, 183.

- and Ducharme, J. R. (1966). Thyroiditis in children. Pediat. Clin. N. Amer., 13, 19.

Lindsten, J., Bowen, P., Lee, C. S. N., McCusick, V. A., Polani, P. E., Wingate, M., Edwards, J. H., Hamper, J., Tippett, P., Sanger, R., and Race, R. R. (1963). Source of the X in XO females: the evidence of $\mathrm{Xg}$. Lancet, $1,558$.

Litman, N. N. (1968). Down's syndrome, hypothyroidism, and diabetes mellitus. f. Pediat., 73, 798.

Lunde, P. K. M. (1959). Samtidig forekomst av mongolisme og hypothyreose. T. norske Laegeforen., 79, 394.

Marañon, G., Martinez Diaz, J., and Gochi Mendizabal, J. M. (1951). Mongolisme et macrogénitosomie. Ann. Endocr. (Paris), 12, 41.

Matsaniotis, N., Karpouzas, J., and Economou-Mavrou, C. (1967). Hypothyroidism and seminoma in association with Down's syndrome. F. Pediat., 70, 810.

Mellon, J. P., Pay, B. Y., and Green, D. M. (1963). Mongolism and thyroid autoantibodies. F. ment. Defic. Res., 7, 31 .

Moore, J. M., and Neilson, J. McE. (1963). Antibodies to gastric mucosa and thyroid in diabetes mellitus. Lancet, 2, 645.

Nickey, L. N. (1960). Thyrotoxicosis in a mongoloid child. Amer. F. Dis. Child., 99, 680.

Nilsson, L. R., and Doniach, D. (1964). Auto-immune thyroiditis in children and adolescents. I. Clinical studies. Acta paediat. (Uppsala), 53, 255.

Owen, S. G., and Smart, G. A. (1958). Thyroid antibodies in myxoedema. Lancet, 2, 1034.

Pabst, H. F., Pueschel, S., and Hillman, D. A. (1967). Etiologic inter-relationship in Down's syndrome, hypothyroidism, and precocious sexual development. Pediatrics, 40, 590.

Penrose, L. S., and Smith, G. F. (1966). Down's Anomaly. Churchill, London.

Robertson, J., Mellon, J. P., and Stewart, J. S. S. (1965). Down's syndrome with unusual karyotype and thyroid autoantibodies. f. ment. Defic. Res., 9, 157.

Roitt, I. M., Doniach, D., Campbell, P. N., and Hudson, R. V. (1956). Auto-antibodies in Hashimoto's disease (lymphadenoid goitre). Lancet, 2, 820.

Saxena, K. M. (1965). Inheritance of thyroglobulin antibody in thyrotoxic children. Lancet, 1, 583.

- , and Crawford, J. D. (1962). Juvenile lymphocytic thyroiditis. Pediatrics, 30, 917.

- and Pryles, C. V. (1965). Thyroid function in mongolism. f. Pediat., 67, 363.

Sparkes, R. S., and Motulsky, A. G. (1963). Hashimoto's disease in Turner's syndrome with isochromosome $\mathrm{X}$. Lancet, 1, 947.

Subrt, I., Blehovâ, B., and Kučera, J. (1968). Aberrant chromosome 13-15 in a patient with Down's syndrome, diabetes mellitus and hyperthyroidism and his father. Acta genet. (Basel), 18, 38.

Talbot, N. B., Sobel, E. H., McArthur, J. W., and Crawford, J. D. (1952). Functional Endocrinology From Birth Through Adolescence. Harvard University Press, Cambridge, Mass.

Vallotton, M. B., and Forbes, A. P. (1967). Autoimmunity in gonadal dysgenesis and Klinefelter's syndrome. Lancet, 1, 648.

Wilkins, L. (1965). The Diagnosis and Treatment of Endocrine Disorders in Childhood and Adolescence, 3rd ed. Thomas, Springfield, Illinois.

Winter, J., Eberlein, W. R., and Bongiovanni, A. M. (1966). The relationship of juvenile hypothyroidism to chronic lymphocytic thyroiditis. F. Pediat., 69, 709. 